\title{
Review on Korarima (Aframomum Corrorima (Braun) P.C.M. Jansen) Research Achievements, Challenges and Future Prospective in Ethiopia
}

\author{
Mohammedsani Zakir \\ Ethiopian Institute of Agricultural Research; Jimma Agricultural Research Center, Jimma Ethiopia \\ *Corresponding Author: Mohammedsani Zakir, Ethiopian Institute of Agricultural Research; Jimma \\ Agricultural Research Center, Jimma Ethiopia
}

\begin{abstract}
The spice, known as korarima, Ethiopian cardamom, or false cardamom, is obtained from the plant's seeds (usually dried), and is extensively used in Ethiopian cuisine. Genetic divergence among korarima accessions shows significance difference between all cluster distances. The minimum squared distance was between cluster III and IV (67.75) followed by cluster I and II (82.12). Maximum squared distance was between cluster II and IV (408.27) followed by cluster II and III (240.57) and cluster I and IV (218.75) thus, increasing parental distance implies a great number of contrasting alleles at the desired loci, and then to the extent that these loci recombine in the F2 and F3 generation following a cross of distantly related parents, the greater will be the opportunities for the effective selection for yield factors of korarima through breeding. In vitro induction of tetraploidy in korarima was attained through the treatment of cultured shoots with a solution of $125 \mu \mathrm{M}$ colchicine or $10 \mu \mathrm{M}$ oryzalin, which were the lowest concentrations tested. Maximum oleoresin content $(10.04 \% \mathrm{w} / \mathrm{w})$ was recorded from mature green capsules dried on wire mesh for 10 days and next to this oleoresin content $(9.16 \% \mathrm{w} / \mathrm{w})$ was obtained still from seeds of mature green capsules dried on the ground for 10 days. In contrast, the minimum oleoresin content (4.87\%) was recorded from mature deep-red capsules dried on cement floor for 20 days. Findings of this study suggest that the maintenance of shade trees on the main farm field is the main requirement for korarima production. Korarima production was declining mainly due to destruction of the plant's natural habitat, therefore the effort should be made on creating the awareness on conservation of the natural forests in Ethiopia.
\end{abstract}

Keywords: Korarima, achievement, Challenge, Prospective, Ethiopia

\section{INTRODUCTION}

Aframomum corrorima is a species in the ginger family, Zingiberaceae. The spice, known as korarima, Ethiopian cardamom, or false cardamom, is obtained from the plant's seeds (usually dried), and is extensively used in Ethiopian cuisine (Braun, 2011). It is an ingredient in berbere, mitmita, awaze, and other spice mixtures, and is also used to flavor coffee (Bernard R. and François V., 2003). In Ethiopian herbal medicine, the seeds are used as a tonic, carminative, and laxative (Bernard R. and François V., 2003). The plant is native to Tanzania, western Ethiopia (in the vicinity of Lake Tana and Gelemso), south western Sudan, western Uganda(Braun, 2011). As indigenous spice, Aframomum corrorima grows in various parts of the country; Kaffa, Jimma, East and West Wollega, Sidamo, Bale, South and North Omo, Illubabour, East and West Gojam, Gamugofa, etc. (Jansen, 1981; Edossa, 1998; Simegn et al., 2016).

Korarima production is declining mainly due to destruction of the plant's natural habitat. A survey was conducted in the three major korarima growing administrative zones, Gamo Gofa, Debub Omo and Kaffa in southern Ethiopia to assess indigenous production practices, wealth status, and farm based biodiversity and household characteristics using participatory rural appraisal (PRA) and semistructured questionnaires. Findings of this study suggest that the maintenance of shade trees on the main farm field is the main requirement for korarima production (Eyob, 2009). Korarima product quality is influenced by, among others, harvesting stages, drying structures and durations. It faces stringent market challenges, due to its inferior oleoresin and essential oil content, with Indian Cardamom. The seeds of korarima contain different types of essential oils having typical odour 
Review on Korarima (Aframomum Corrorima (Braun) P.C.M. Jansen) Research Achievements, Challenges and Future Prospective in Ethiopia

(Jansen 1981; Abegaz et al., 1994; Eyob et al., 2007) and are traditionally used as tonic, carminative and purgative drug. From a formal survey, korarima seeds, pods, leaves, rhizomes and flowers are used in southern Ethiopia as traditional medicine for human and animal ailments caused by unknown agents; and particularly used to treat any part of the animal body upon swelling (Eyob et al., 2008). This review was conducted to identify the achievement, challenges and prospects of korarima production of Ethiopia.

\section{RESEARCH ACHIEVEMENT OF KORARIMA IN ETHIOPIA}

\subsection{Genetic Diversity Studies on Yield and its Related Traits in Korarima Germplasms}

\subsubsection{Cluster analysis}

Cluster analysis grouped 25 accessions in to four distinct groups (Table 2) in which the first cluster (CL1) consisted of 9 accession which is (36\%), the second cluster ( CL2) 6 accessions (24\%), the third cluster (CL3) 8 accessions (32\%) and fourth cluster (CL4) contained 2 accession (8\%). Collections from SNNP regional states were almost distributed in all clusters than Amhara and Oromia regional states indicating the existence of more genetic diversity in this region than Amhara and Oromia regional states and accession from the same origin might have different genetic background (Simegn et al., 2016).

Table2: Distribution of germplasm accession in to four clusters based on D2 analysis for 25 korarima accessions studied at JARC 2011/12

\begin{tabular}{|c|c|c|c|}
\hline Clusters & Number Germplasm & Serial Number & $\begin{array}{r}\text { Region } \\
\end{array}$ \\
\hline \multirow[t]{9}{*}{ Cluster I } & \multirow[t]{9}{*}{9} & $015 / 3$ & Oromia \\
\hline & & $053 / 3$ & SNNPRS \\
\hline & & $068 / 87$ & Amhara \\
\hline & & $701 / 87$ & SNNPRS \\
\hline & & $010 / 00$ & SNNPRS \\
\hline & & $028 / 84$ & Oromia \\
\hline & & $105 / 03$ & Oromia \\
\hline & & $001 / 03$ & SNNPRS \\
\hline & & $046 / 03$ & Oromia \\
\hline \multirow[t]{6}{*}{ Cluster II } & \multirow[t]{6}{*}{6} & $029 / 84$ & Oromia \\
\hline & & $011 / 00$ & SNNPRS \\
\hline & & $045 / 03$ & SNNPRS \\
\hline & & $001 / 84$ & Oromia \\
\hline & & $114 / 03$ & Oromia \\
\hline & & $059 / 03$ & Oromia \\
\hline \multirow[t]{8}{*}{ Cluster III } & \multirow[t]{8}{*}{8} & Jimma Local & Oromia \\
\hline & & 093/03 & Amhara \\
\hline & & $025 / 03$ & Oromia \\
\hline & & $009 / 00$ & Amhara \\
\hline & & $016 / 84$ & Oromia \\
\hline & & $038 / 01$ & SNNPRS \\
\hline & & $021 / 84$ & SNNPRS \\
\hline & & $686 / 87$ & Amhara \\
\hline \multirow[t]{2}{*}{ Cluster IV } & \multirow[t]{2}{*}{2} & $018 / 00$ & SNNPRS \\
\hline & & $014 / 00$ & Amhara \\
\hline
\end{tabular}

Source: Simegn et al., 2016

\subsubsection{Genetic Divergence among Accessions}

Test of significance show significance difference between all cluster distances (Table 2). The minimum squared distance was between cluster III and IV (67.75) followed by cluster I and II (82.12). Maximum squared distance was between cluster II and IV (408.27) followed by cluster II and III (240.57) and cluster I and IV (218.75) (Simegn et al., 2016). According to Ghaderi et al. (1984) increasing parental distance implies a great number of contrasting alleles at the desired loci, and then to the extent that these loci recombine in the F2 and F3 generation following a cross of distantly related parents, the greater will be the opportunities for the effective selection for yield factors. 
Review on Korarima (Aframomum Corrorima (Braun) P.C.M. Jansen) Research Achievements, Challenges and Future Prospective in Ethiopia

Table2: Generalized squared distance among four clusters in 25 korarima germplasm accession studied at JARC 2011/12.

\begin{tabular}{|c|c|c|c|}
\hline Cluster & \multicolumn{1}{|c|}{ II } & \multicolumn{1}{c|}{ III } \\
\hline & $182.12^{* *}$ & $111.42^{* *}$ & $218.75^{* *}$ \\
\hline I & & $240.57^{* *}$ & $408.27^{* *}$ \\
\hline II & & $240.57^{* *}$ & $408.27^{* *}$ \\
\hline III & & & $67.75^{* *}$ \\
\hline
\end{tabular}

Source: Simegn et al., 2016

\subsection{In Vitro Chromosome Doubling in Korarima Using Colchicine and Oryzalin}

\subsubsection{Chromosome Count}

The chromosomes of korarima were observed to be small in size (Figure 1) and their diploid number was found to be $2 n=2 \mathrm{x}=48$ (Figure 2). In vitro induction of tetraploidy in korarima was attained through the treatment of cultured shoots with a solution of $125 \mu \mathrm{M}$ colchicines or $10 \mu \mathrm{M}$ oryzalin, which were the lowest concentrations tested. In general, the relatively less toxic nature of oryzalin together with its affordability makes it by far the best candidate for future in vitro polyploid induction work with korarima. In all cases, tetraploid korarima plantlets revealed vigorous growth, possessing thicker and large-sized leaves that were deep green in color. Of the different morphological characters evaluated, those related with stomata (density and length) could serve as a quick technique to segregate and pre-select putative polyploid plants (Surawit and Wondyifraw, 2013).

The presumed polyploid plantlets generally exhibited reduced stomatal density $(3.16-4.20 \mathrm{~mm}-2)$ and longer stomata $(14.75-16.52 \mu \mathrm{m})$ and in some cases lower stomatal indices (5.06-6.48) than the controls that were recorded at a mean of $9.58 \mathrm{~mm}-2,11.38 \mu \mathrm{m}$ and 10.20 for the respective parameters ( Figures 1a and 1b).

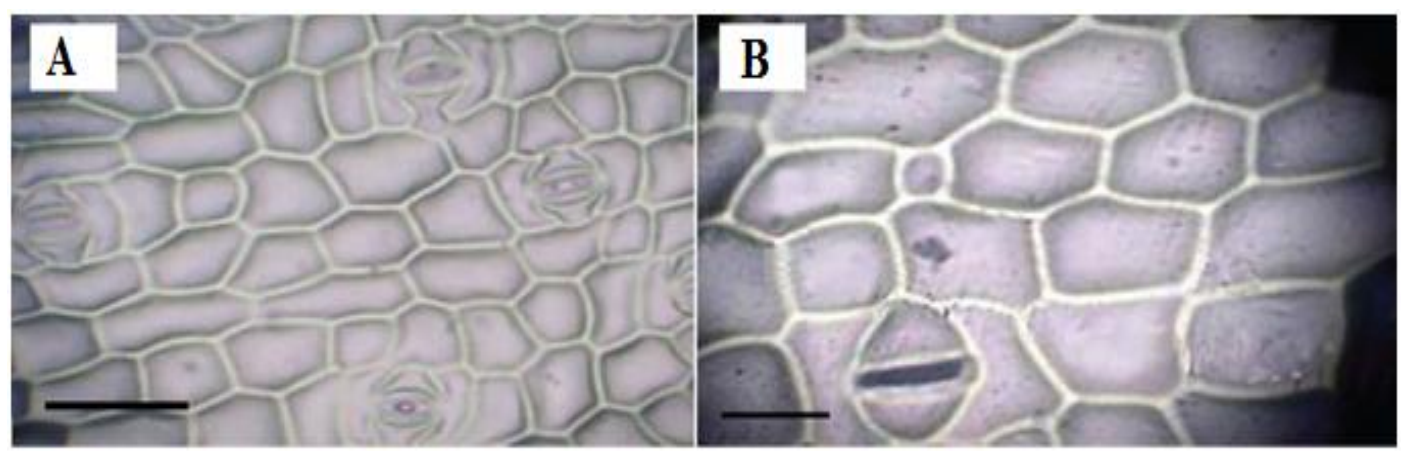

Figure1: Stomata from the abaxial leaf epidermis: (a) Diploid and (b) Tetraploid korarima shoots (Scale bar = $25 \mu \mathrm{m}$.

Source: Surawit and Wondyifraw, 2013

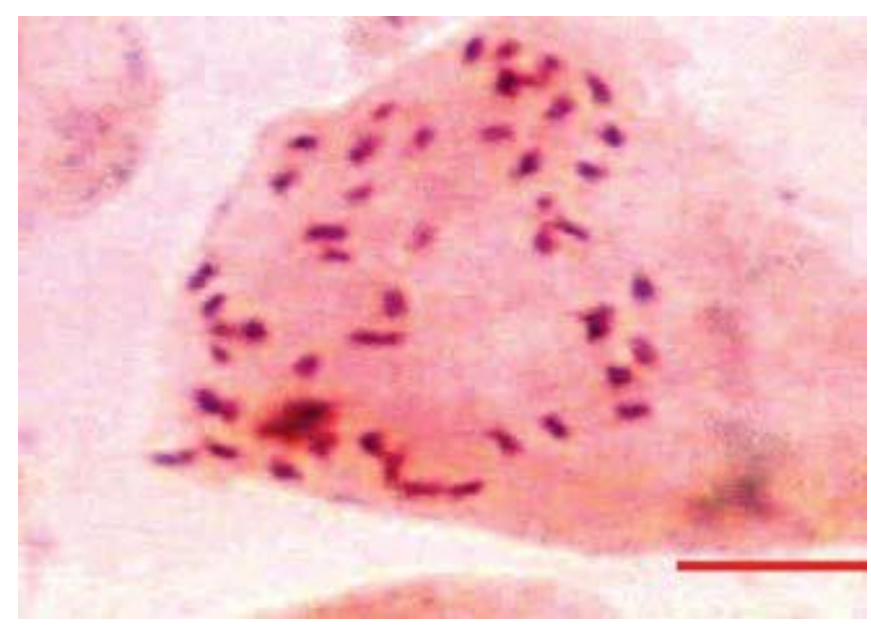

Figure2: Mitotic chromosomes of a diploid

Korarima plant $(2 n=48)$. (Scale bar $=10 \mu \mathrm{m}$. 
Review on Korarima (Aframomum Corrorima (Braun) P.C.M. Jansen) Research Achievements, Challenges and Future Prospective in Ethiopia

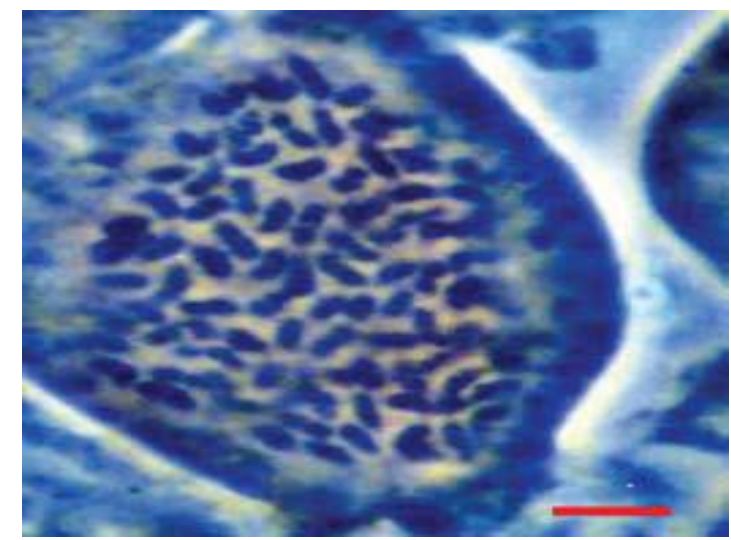

Figure3: Mitotic chromosomes of a tetraploid korarima plant $(2 n=4 x=96) .10 \mu m$. $)$

Source: Surawit and Wondyifraw, 2013

\subsection{Influence of Harvesting Stages, Drying Structures and Drying Durations on Oleoresin and Essential Oil content of Korarima Capsules}

\subsubsection{Collection, Drying and Extraction Procedure}

Harvesting of the capsules was done based on visual observation of physical appearance, color and size. In addition, easiness to detach the capsules from mother stalk plant and complete dry up of the capsule upper tip (straw) were also taken into account during harvesting. Capsules which were free from insect or physical damage, unbleached, uniform in color for the particular stage were considered during the harvesting time (Fissiha et al., 2014).

\subsubsection{Oleoresin Content of Dried Seeds}

The results of the present study indicated that the interaction effects among various harvesting stages, drying structures and drying durations on oleoresin content of dried seeds were observed highly significantly different $(\mathrm{p}<0.001)$. Maximum oleoresin content $(10.04 \% \mathrm{w} / \mathrm{w})$ was recorded from mature green capsules dried on wire mesh for 10 days and next to this oleoresin content $(9.16 \% \mathrm{w} / \mathrm{w})$ was obtained still from seeds of mature green capsules dried on the ground for 10 days. In contrast, the minimum oleoresin content $(4.87 \%)$ was recorded from mature deep-red capsules dried on cement floor for 20 days (Table 3). It is apparent that the maximum result exceeded $51.49 \%$ and $33.76 \%$ from the minimum result and grand mean, respectively. Mature deep-red capsules dried on cement floor for longer time have got low oleoresin content at the expense of high exposure to solar radiation and depletion of the volatiles and non-volatiles which resulted in decreased oleoresin content. It is unambiguous that when harvesting stage extended, oleoresin content decreased owing to the commencement of ripening which require expenditure of volatiles and non-volatiles. Following the same trend, as the drying duration extended, oleoresin content found to be decreased which might be due to depletion of volatiles and non-volatiles of dried seeds resulted from prolonged exposure to solar exposure (Fissiha et al., 2014).

Table3: Interaction effect among different harvesting stages, drying structures and drying durations on oleoresin content of dried seeds $(\% \mathrm{~W} / \mathrm{W})$

\begin{tabular}{|c|c|c|c|c|c|c|c|c|c|}
\hline \multirow{3}{*}{$\begin{array}{c}\text { Drying } \\
\text { Structures }\end{array}$} & \multicolumn{9}{|c|}{ Harvesting Stages by Drying Durations } \\
\hline & \multicolumn{3}{|c|}{ Mature Green (MG) } & \multicolumn{3}{|c|}{ Mature Semi-Red(MS) } & \multicolumn{3}{|c|}{ Mature Deep Red(MR) } \\
\hline & 10 Days & 15 Days & $\begin{array}{c}20 \\
\text { Days }\end{array}$ & $\begin{array}{c}10 \\
\text { Days }\end{array}$ & $\begin{array}{c}15 \\
\text { Days }\end{array}$ & $\begin{array}{c}20 \\
\text { Days }\end{array}$ & $\begin{array}{c}10 \\
\text { Days }\end{array}$ & $\begin{array}{c}15 \\
\text { Days }\end{array}$ & $\begin{array}{c}20 \\
\text { Days }\end{array}$ \\
\hline Cement & $7341 \mathrm{~g}$ & $6.073 \mathrm{~m}$ & $5.455 \mathrm{o}$ & $6.635 \mathrm{j}$ & $5.528 \mathrm{o}$ & $5.158 \mathrm{p}$ & $6.048 \mathrm{~m}$ & $5.177 \mathrm{p}$ & $4.874 \mathrm{r}$ \\
\hline Ground & $9.159 \mathrm{~b}$ & $7.430 \mathrm{~g}$ & $6.415 \mathrm{k}$ & $7.742 \mathrm{e}$ & 6.2531 & $5.182 \mathrm{n}$ & $6.859 \mathrm{i}$ & 5.5260 & $5.027 \mathrm{q}$ \\
\hline Wire mesh & $10.035 \mathrm{a}$ & $8.443 \mathrm{c}$ & $7.549 \mathrm{f}$ & $8.284 \mathrm{~d}$ & $7.074 \mathrm{~h}$ & $6.49 \mathrm{k}$ & $7.069 \mathrm{~h}$ & 6.2141 & $5.777 \mathrm{n}$ \\
\hline Grand Mean & \multicolumn{9}{|c|}{6.646} \\
\hline LSD (0.05) & \multicolumn{9}{|c|}{0.112} \\
\hline CV $(\%)$ & \multicolumn{9}{|c|}{1.035} \\
\hline
\end{tabular}

Means sharing the same letter(s) are not significantly different at $p=0.05$ according to LSD test.

Source: Fissiha et al., 2014 
Review on Korarima (Aframomum Corrorima (Braun) P.C.M. Jansen) Research Achievements, Challenges and Future Prospective in Ethiopia

\subsubsection{Essential Oil Content of Dried Seeds}

Results of the current experiment revealed that the interaction effect among the various harvesting stages, drying structures and drying durations on essential oil (EO) content of dried seeds was very highly significant $(\mathrm{p}<0.0001)$. According to the result presented in Table 4 , the maximum value for EO content of dried seeds was recorded from mature green capsules harvested and dried on wire mesh for 10 days $(5.53 \%)$ which was statistically at par with mature semi-red capsules dried on wire mesh for 10 days $(5.35 \%)$. On the other hand, the minimum EO content was recorded from mature green capsules dried on cement floor for 20 days (CMGD3) $(2.82 \% \mathrm{v} / \mathrm{w})$. Mature semi-red capsules dried on cement floor for 15 days and 20 days both recorded the same result (3.05\%) which was statistically similar to the result of CMGD3. About $49.11 \%$ difference was recorded between the maximum and minimum results of EO content of dried seeds. Furthermore, the maximum result was found to be $24.95 \%$ higher than the grand mean. Early harvested mature and green color capsules and dried on wire mesh for short drying duration (10 days) had high EO content due to low exposure of capsules to solar radiation and high air circulation in wire mesh drying structure while cement floor drying structure scored low results due to longer exposure to higher solar radiation. As late harvesting stage (mature semi-red and mature deep-red) exercised, the EO content of dried seeds decreased and this reconfirmed that harvesting at a given stage of maturity is a significant factor affecting quality of spices (Purseglove,1981). It is apparent that as ripening commenced, metabolic activity will take place which may result in reduction of EO of dried seeds as it could be used exhaustively. Leela et al.,2008 Proved this fact which stated that in all small cardamom genotypes, the highest mean EO yield was obtained at immature stage, which was at par with that of physiologically mature stage whereas the least oil yield was recorded at fully ripe stage. In the same way, when the drying duration extended the EO content of dried seeds decreased may be due to the volatility nature and heat sensitivity of the oils. Purseglove, 1981 also elaborated that in most of the spices essential oils are maximum at earlier harvest stages and under the fruit maturation process the fruits undergo a physicchemical changes and this definitely affect the quantity of essential oils. After distillation of dried comminuted fruits, $3-3.5 \%$ of a pale yellow volatile oil with a flat cineolic odour can be obtained, in which the following compounds have been found (all monoterpenes, approximate amount of the major ones): 1,8-cineol 32-35\%, limonene 7-14\%, $\beta$-pinene 4-7\%, sabinene 7-9\%, terpinen-4-ol 3$5 \%$, geraniol 5\%, P-cymene 4\%, $\alpha$-pinene, $\alpha$-terpineol and $\gamma$-terpinene 3\% each (Simegn et al., 2016). Sesquiterpenes were identified in another analysis; the total was dominated by about $75 \%$ monoterpenes including 1,8-cineol (38\%) and terpinyl acetate $(11 \%)$, and $17 \%$ sesquiterpenes including nerolidol (11-14\%), $\beta$ - caryophyllene (2\%) and caryophyllene oxide 1\% ( Eyob et al., 2007 and Simegn et al., 2016 ).

\begin{tabular}{|c|c|c|c|c|c|c|c|c|c|}
\hline \multirow{3}{*}{$\begin{array}{c}\text { Drying } \\
\text { Structures }\end{array}$} & \multicolumn{9}{|c|}{ Harvesting Stages by Drying Durations } \\
\hline & \multicolumn{3}{|c|}{ Mature Green (MG) } & \multicolumn{3}{|c|}{ Mature Semi-Red(MS) } & \multicolumn{3}{|c|}{ Mature Deep Red(MR) } \\
\hline & 10 Days & 15 Days & $\begin{array}{c}20 \\
\text { Days }\end{array}$ & $\begin{array}{c}10 \\
\text { Days }\end{array}$ & $\begin{array}{c}15 \\
\text { Days }\end{array}$ & $\begin{array}{c}20 \\
\text { Days }\end{array}$ & $\begin{array}{c}10 \\
\text { Days }\end{array}$ & $\begin{array}{c}15 \\
\text { Davs }\end{array}$ & $\begin{array}{c}20 \\
\text { Davs }\end{array}$ \\
\hline Cement & $3.833 \mathrm{ijk}$ & 3.1331 & $\begin{array}{l}2.816 \\
\mathrm{~m}\end{array}$ & $\begin{array}{l}4.050 f \\
\text { ghi }\end{array}$ & $\begin{array}{l}3.0501 \\
\mathrm{~m}\end{array}$ & $\begin{array}{l}3.0501 \\
\mathrm{~m}\end{array}$ & $4.283 \mathrm{ef}$ & 3.2001 & 3.2001 \\
\hline Ground & $5.116 \mathrm{~b}$ & $4.553 \mathrm{~d}$ & $\begin{array}{l}4.033 \mathrm{~g} \\
\mathrm{hi}\end{array}$ & $4.866 \mathrm{c}$ & $4.283 \mathrm{rf}$ & $\begin{array}{l}3.766 j \\
k\end{array}$ & $4.450 \mathrm{de}$ & $\begin{array}{l}4.200 \mathrm{f} \\
\mathrm{g}\end{array}$ & $3.683 \mathrm{k}$ \\
\hline Wiremesh & $5.533 \mathrm{a}$ & $5.116 \mathrm{~b}$ & $4.553 \mathrm{~d}$ & $\begin{array}{l}5.350 \mathrm{a} \\
\mathrm{b}\end{array}$ & $4.583 \mathrm{~d}$ & $\begin{array}{l}4.116 \mathrm{f} \\
\text { gh }\end{array}$ & $4.866 \mathrm{c}$ & $\begin{array}{l}4.283 \mathrm{e} \\
\mathrm{f}\end{array}$ & $\begin{array}{l}3.950 \mathrm{~h} \\
\mathrm{ij}\end{array}$ \\
\hline Grand Mean & & & & & 4.144 & & & & \\
\hline LSD (0.05) & & & & & 0.242 & & & & \\
\hline CV (\%) & & & & & 3.567 & & & & \\
\hline
\end{tabular}

Means sharing the same letter(s) are not significantly different at $p=0.05$ according to LSD test.

Source: Fissiha et al., 2014

\subsubsection{Essential Oil Content of Dried Husk}

The result of the current investigation exhibited that the interaction effect among various harvesting stages, drying structures and drying durations on essential oil (EO) content of dried Korarima husk was very highly significantly affected $(\mathrm{p}<0.0001)$. The result presented in Table 3 , illustrated that the maximum result was recorded from mature green capsules dried on wire mesh for 10 days $(0.933 \%)$ 
Review on Korarima (Aframomum Corrorima (Braun) P.C.M. Jansen) Research Achievements, Challenges and Future Prospective in Ethiopia

while the minimum values were attained from mature green capsules dried on cement floor for 20 days $(0.42 \%)$, mature semi-red dried on cement floor for 15 days and 20 days resulted $(0.46 \%)$ and $(0.48 \%)$, respectively and showed no statistical difference to each other (Table 5).

Table5: Interaction effect among different harvesting stages, drying structures and drying durations on essential oil content dried husks of korarima $(\% \mathrm{~V} / \mathrm{W})$

\begin{tabular}{|c|c|c|c|c|c|c|c|c|c|}
\hline \multirow{3}{*}{$\begin{array}{c}\text { Drying } \\
\text { Structures }\end{array}$} & \multicolumn{9}{|c|}{ Harvesting Stages by Drying Durations } \\
\hline & \multicolumn{3}{|c|}{ Mature Green (MG) } & \multicolumn{3}{|c|}{ Mature Semi-Red(MS) } & \multicolumn{3}{|c|}{ Mature Deep Red(MR) } \\
\hline & 10 Days & 15 Days & $\begin{array}{c}20 \\
\text { Days }\end{array}$ & $\begin{array}{c}10 \\
\text { Days }\end{array}$ & $\begin{array}{c}15 \\
\text { Days }\end{array}$ & $\begin{array}{c}20 \\
\text { Days }\end{array}$ & $\begin{array}{c}10 \\
\text { Days }\end{array}$ & $\begin{array}{c}15 \\
\text { Days }\end{array}$ & $\begin{array}{c}20 \\
\text { Days }\end{array}$ \\
\hline Cement & $\begin{array}{l}0.526 \mathrm{ijk} \\
1 \mathrm{~m}\end{array}$ & $\begin{array}{l}0.516 \mathrm{jkl} \\
\mathrm{m}\end{array}$ & $0.423 n$ & $\begin{array}{l}0.576 \mathrm{~g} \\
\text { hij }\end{array}$ & $\begin{array}{l}0.463 \\
\mathrm{mn}\end{array}$ & $\begin{array}{l}0.4761 \\
\mathrm{mn}\end{array}$ & $0.640 \mathrm{fg}$ & $\begin{array}{l}0.520 \mathrm{ij} \\
\mathrm{klm}\end{array}$ & $\begin{array}{l}0.493 \mathrm{k} \\
\mathrm{lm}\end{array}$ \\
\hline Ground & $0.773 b c$ & $\begin{array}{l}0.713 c d \\
e^{-}\end{array}$ & $\begin{array}{l}0.533 \mathrm{ij} \\
\mathrm{kl}\end{array}$ & $\begin{array}{l}0.720 \mathrm{c} \\
\mathrm{d}\end{array}$ & $\begin{array}{l}0.553 \mathrm{ij} \\
\mathrm{k}\end{array}$ & $\begin{array}{l}0.523 \mathrm{ij} \\
\mathrm{klm}\end{array}$ & $0.650 \mathrm{ef}$ & $\begin{array}{l}0.583 \mathrm{~g} \\
\mathrm{hi}\end{array}$ & $\begin{array}{l}0.533 \mathrm{ij} \\
\mathrm{kl}\end{array}$ \\
\hline Wiremesh & $0.933 \mathrm{a}$ & $0.770 \mathrm{bv}$ & $\begin{array}{l}0.630 \mathrm{f} \\
\mathrm{g}\end{array}$ & $0.833 b$ & $\begin{array}{l}0.673 d \\
\text { ef }\end{array}$ & $\begin{array}{l}0.626 \mathrm{f} \\
\mathrm{gh}\end{array}$ & $0.766 \mathrm{c}$ & $\begin{array}{l}0.626 \mathrm{f} \\
\mathrm{gh}\end{array}$ & $\begin{array}{l}0.563 \mathrm{~h} \\
\mathrm{ij}\end{array}$ \\
\hline Grand Mean & & & & & 0.616 & & & & \\
\hline LSD (0.05) & & & & & 0.067 & & & & \\
\hline CV (\%) & & & & & 6.593 & & & & \\
\hline
\end{tabular}

Means sharing the same letter(s) are not significantly different at $\mathrm{p}=0.05$ according to LSD test.

Source: Fissiha et al., 2014

Therefore, it can be concluded that the result of the current study showed that the combined effect of the various harvesting stages, drying structures and durations have sound and promising impact on oleoresin content of dried seeds and essential oil content of dried seeds and husks of Korarima. Generally, drying on Wire mesh structure was found to be consistently superior in resulting of better chemical quality attributes and can be recommended for higher oleoresin and essential oil production. Hence, when the capsules are intended for immediate extraction purpose, mature green capsules dried on wire mesh for 10 days can be recommended for high oleoresin and essential oil production. Thus, collectors/producers in all Korarima growing areas of Ethiopia better to be aware of the quality issues and may use the recommendations for better oleoresin and essential oil (Fissiha et al., 2014).

\subsection{Influence of Rooting Media on Nursery Performance of Korarima}

\subsubsection{Plant height and leaf length}

The highest mean values of plant height and leaf length of Korarima was recorded $45 \mathrm{~cm}$ and $14.25 \mathrm{cmrespectivelyfor} \mathrm{seeds} \mathrm{sown} \mathrm{in} \mathrm{frost} \mathrm{soil} \mathrm{(Table} \mathrm{6).} \mathrm{The} \mathrm{minimum} \mathrm{value} \mathrm{of} \mathrm{plant} \mathrm{height} \mathrm{was}$ recorded on sand soil at $32.42 \mathrm{~cm}$, similarly $10.79 \mathrm{~cm}$ for the leaf length also. Soil of high organic matter has an excellent watering holding capacity and media needed as growth of seedling increase to escape from the stress to get tolerant and high number of transplanting seedling and this show that seeds sown in forest soil ( Mohammed ,2004 ;Jafer et al.,2014 and Lupi et al.,2016)

\subsubsection{Tiller production, leaf area and leaf numbers}

On the other side the tiller production of Korarima is not significantly different in forest soil, decomposed coffee husk and mixing of fine sand and forest soil .The leaf area of Korarima variety significantly affected to the rooting media as a whole, with recorded the highest value $56.37 \mathrm{~cm} 2$ and lowest one recorded in $37.6 \mathrm{~cm} 2$ on forest and fine sand soil respectively. Whereas, the number of leaf significantly responded to the frost soil with highest value of 23.83 and the lowest value was observed in sand soil 15.25 (Table 6).

Table6: Effects of rooting media performance on plant height, leaf length, tiller production, leaf areas, and leaf number of Korarima

\begin{tabular}{|c|c|c|c|c|c|}
\hline Treatments & $\begin{array}{c}\text { Plant } \\
\text { Height }(\mathrm{cm})\end{array}$ & Leaf Length $(\mathrm{cm})$ & Tiller Number & $\begin{array}{c}\text { Leaf Area } \\
(\mathrm{cm} 2)\end{array}$ & $\begin{array}{c}\text { Number of } \\
\text { Leaves }\end{array}$ \\
\hline FS & $32.42 \mathrm{~d}$ & $10.79 \mathrm{c}$ & 1.75 & $37.6 \mathrm{c}$ & $15.25 \mathrm{~b}$ \\
\hline ForS & $45 \mathrm{a}$ & $14.25 \mathrm{a}$ & 3.58 & $56.37 \mathrm{a}$ & $23.83 \mathrm{a}$ \\
\hline DCH & $40.67 \mathrm{bc}$ & $12.56 \mathrm{ab}$ & 3.65 & $49.75 \mathrm{ab}$ & $19.25 \mathrm{ab}$ \\
\hline
\end{tabular}


Review on Korarima (Aframomum Corrorima (Braun) P.C.M. Jansen) Research Achievements, Challenges and Future Prospective in Ethiopia

\begin{tabular}{|c|c|c|c|c|c|}
\hline FS+ForS & $40.62 \mathrm{bc}$ & $12.42 \mathrm{~b}$ & 3.62 & $43.33 \mathrm{bc}$ & $20.89 \mathrm{ab}$ \\
\hline FS+DCH & $37.5 \mathrm{c}$ & $12.58 \mathrm{ab}$ & 1.92 & $40.58 \mathrm{c}$ & $15.83 \mathrm{~b}$ \\
\hline ForS+DCH & $41.09 \mathrm{bc}$ & $12.69 \mathrm{ab}$ & 2.58 & $45.43 \mathrm{bc}$ & $18.78 \mathrm{ab}$ \\
\hline FS+ForS+DCH & $42.17 \mathrm{ab}$ & $13.03 \mathrm{ab}$ & 3.67 & $45.57 \mathrm{bc}$ & $21.75 \mathrm{ab}$ \\
\hline LSD $(0.05)$ & 3.84 & 1.76 & 2.13 & 8.67 & 6.53 \\
\hline CV & $5.4^{* *}$ & $7.91^{* *}$ & $40.36 \mathrm{~ns}$ & $10.71^{* *}$ & $18.96^{* *}$ \\
\hline
\end{tabular}

$F S=$ Fine sandy, ForS = forest soil, DCH = decomposed coffee husk, FS + ForS = mixture of sandy soil and forest soil, $F S+D C H=$ mixture of sandy soil and decomposed coffee husk, ForS + DCH =forest soil and decomposed coffee husk

Source: Lupi et al., 2016

\section{Challenges of Korarima Production in EThiopia}

Aframomum corrorima with its magnificent uses of for the nation, it has lots of challenges. Till present all production and post harvest processing practices of Aframomum corrorima capsules are very traditional which automatically contributed for low quality products. As the spice is collected from inside the wild forest, the capsules are harvested mostly at immature green and mature green stage because of competition among competitive spice collectors from the natural forest and wild animals (Apes, Monkeys, Squirrels, snakes). There were no improved varieties for recommendation to the large scale production in order to increase the production, productivity and quality of the Ethiopian Korarima. Poor production and marketing system of Aframomum corrorima discourage farmers to produce more. The study identified that $86 \%, 74.50 \%, 41 \%, 35.95 \%, 62.10 \%, 52.25 \%$, $32.75 \%$, of sampled farmers confirmed that inadequate fertilizer supply, inadequate planting materials, shortage of access to credit, wild animal competition, price setting, scale and demand, respectively, are the major factors affecting Aframomum corrorima production negatively(Fissiha and Zemed,2015). According to (Eyob et al., 2008) Korarima production is declining mainly due to destruction of the plant's natural habitat (Graph.1).

Graph1: The relationship of the shade tree number and production area

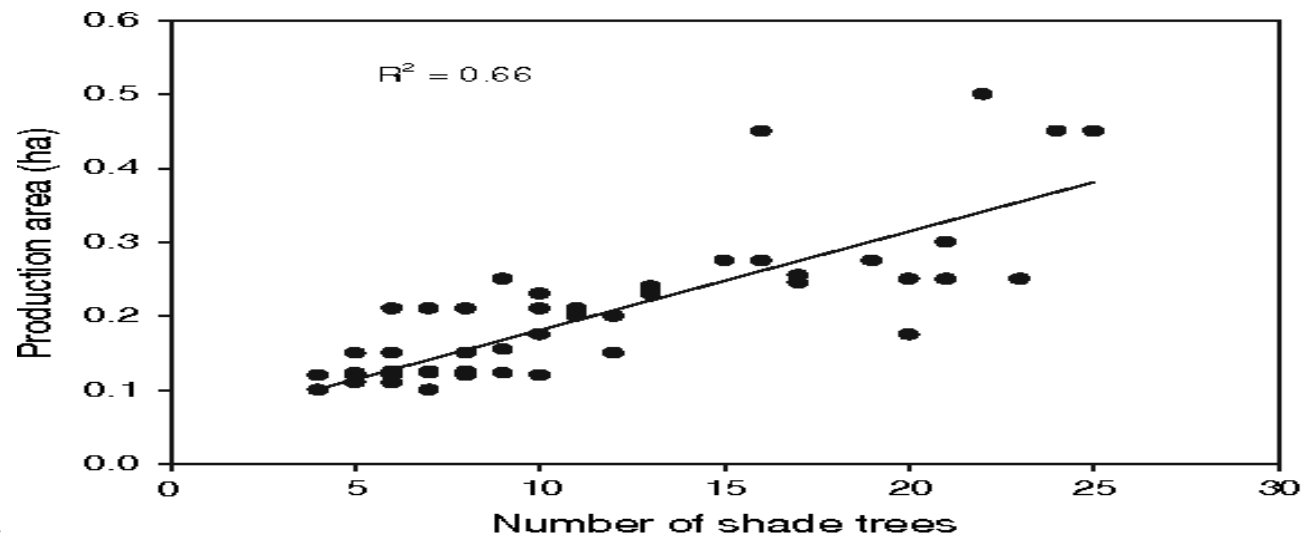

Source: Eyob et al., 2008

\section{Prospective of Korarima Production in Ethiopia}

Since the Country is considered as origin of the crop the large amount of germplasms found in the forest should be collected and preserved in ex-situ condition including in-vitro conservation since the climate change effect is becoming a serious problem for such crop. Screening the collected germplasms for yield, adaptation and quality; in order to develop improved variety that supporting the korarima production and productivity. Maintaining the natural habitat from deforestation, because korarima by nature survive in the forest; which indicate its shade living. Awareness creation on forest conservation should be provided for the Society in order to save the eradication of the korarima germplasm from the forest and support the sustainable production of the crop.

\section{CONCLUSION}

The spice, known as korarima, Ethiopian cardamom, or false cardamom, is obtained from the plant's seeds (usually dried), and is extensively used in Ethiopian cuisine. As indigenous spice, Aframomum corrorima grows in various parts of the country; Kaffa, Jimma, East and West Wollega, Sidamo, 
Bale, South and North Omo, Illubabour, East and West Gojam, Gamugofa but its production is very low due to lack of improved variety. Korarima production is declining mainly due to destruction of the plant's natural habitat; there the effort should be made on creating the awareness on conservation of the natural forests in Ethiopia.

\section{REFERENCES}

[1] Abegaz B, Asfaw N and Lwande W, 1994.Chemical constituents of the essential oil of Aframomum corrorima from Ethiopia. Sinet Ethip. J. Sci. 17:145-148

[2] Braun A., 2011. Aframomum corrorima was published in Spices, Condiments and Medicinal Plants in Ethiopia, Their Taxonomy and Agricultural Significance. National Germplasm Resources Laboratory, Beltsville, Maryland: USDA, ARS, National Genetic Resources Program. Retrieved June 19, 2011. Synonyms:

[3] Bernard R. and François V., 2003. "Natural patrimony and local communities in Ethiopia: geographical advantages and limitations of a system of indications" 29th Annual Spring Symposium of Centre for African Studies.

[4] Eyob S, Appelgren M, Rohloff J, Tsegaye A and Messele G, 2007. Chemical composition and physical properties of essential oils from fresh plant parts of korarima (Aframomum corrorima cultivated in the highland of southern Ethiopia. J. Essent Oil Res. 19:372-375

[5] Eyob S, Appelgren M, Rohloff J, Tsegaye A and Messele G, 2008. Traditional medicinal uses an essential oil composition of leaves and rhizomes of korarima (Aframomum corrorima (Braun) P.C.M. Jansen) from southern Ethiopia. S Afr. J. Bot 74:181-185.

[6] Eyob, S., Tsegaye, A. and Appelgren, M., 2009. Analysis of korarima (Aframomum corrorima (Braun) PCM Jansen) indigenous production practices and farm based biodiversity in southern Ethiopia. Genetic resources and crop evolution, 56(4), pp.573-585

[7] Fissiha G. G. and Zemed Mizan Negash, 2015. Analysis of Major Factors Affecting Production and Marketing of Korarima (Aframomum Corrorima (Braun) P.C.M. Jansen) in Ethiopia ; Journal of Economics and Sustainable Development; Vol.6, No.19; ISSN 2222-1700

[8] Fissiha G.G, Ali M., Girma H., 2014. Influence of Harvesting Stages, Drying Structures and Drying Durations on Oleoresin and Essential Oil content of Korarima (Aframomum corrorima (Braun) P.C.M. Jansen) Capsules Grown in Ethiopia; Agricultural Science, Engineering and Technology Research Vol. 2, No. 4, ISSN: 2333 0953,pp. 1- 8, http://asetr.org/

[9] Ghaderi, A., M.W. Adams and A.M. Nassib, 1984. Relationship between genetic distance and heterosis for yield and morphological traits in dry edible bean and fababean. Crop Science 24:37-42.

[10] Jafer D., Tesfaye S., Amsalu N.,2014.Effect of nursery potting media and watering frequency on emergence and seedling growth of Korarima (Aframomum cororima (Braun) P.C.M.Jansen),sky journal of Agricultural research

[11] Jansen P.C.M, 1981. Spices, condiments and medicinal plants in Ethiopia, their taxonomy and agricultural significance. PhD thesis, Agricultural Research Reports 906. Center for Agricultural Publishing and Documentation, Wageningen, The Netherlands, pp 10-20

[12] Leela, N.K., D. Prasath and M.N. Venugopal, 2008. Essential oil composition of selected cardamom genotypes at different maturity levels. Indian Journal of Horticulture 65(3), September 2008: 366-369.

[13] Lupi A., Temeteme S., Mitiku T., and Mekonen B., 2016. Influence of Rooting Media on Nursery Performance of Korarima (Aframomum corrorima) in Southwest of Ethiopia Academic Research Journal of agricultural Science and Research Vol. 4(2), ISSN: 2360-7874, pp.61-65

[14] Mohammed W., 2004. Response of seedlings of Arabica coffee (Coffea arabica 1.) cultivars to soil water deficit... An M. Sc. Thesis Presented to Graduate Studies of Alemaya University, Alemaya, Ethiopia

[15] Purseglove, J.W., E.G. Brown, C.L. Green, and S.R. Robins, 1981. Spices: Volume 1 and 2. Longman group limited, London.

[16] Simegn K., Sentayehu A., Melaku A.,2016.Genetic Diversity Studies on Yield and Its Related Traits in Korarima (Aframomum Corrorima (Braun) Jansen)) Germplasms; Journal of Biology, Agriculture and Healthcare; Vol.6(3) ISSN 2224-3208

Citation: M. Zakir, "Review on Korarima (Aframomum Corrorima (Braun) P.C.M. Jansen) Research Achievements, Challenges and Future Prospective in Ethiopia", International Journal of Research Studies in Agricultural Sciences, vol. 4, no. 1, p. 29-36, 2018. http://dx.doi.org/10.20431/2454-6224.0401005

Copyright: () 2018 Authors. This is an open-access article distributed under the terms of the Creative Commons Attribution License, which permits unrestricted use, distribution, and reproduction in any medium, provided the original author and source are credited. 